\title{
The Alliance for Progress and the "Developmentalism" in Chile
}

\author{
Armando Di Filippo \\ University of Chile \\ Alberto Hurtado University
}

The governments that preceded the presidency of Jorge Alessandri Rodríguez, implemented a series of industrialist policies that, deliberately or not, signified energetic steps forward in the direction of developmentalism preached by ECLAC in its collaborative action with the Alliance for Progress (ALPRO) promoted by the Democratic government of JF Kennedy.

At the national level, Chile's developmental strategy, supported by ALPRO, not only required technical and financial support measures for the development of the industry, but also a far-reaching historical change, committed to national development and regional integration such as had been proposed by ECLAC on a Latin American scale. ALPRO was implicitly accepting that commitment. However, this great social experiment was demolished with blood and fire by the assassination of the Kennedy brothers and the subsequent installation of military dictatorships in South America.

Keywords: Alliance for Progress, Latin America, John. F. Kennedy, agrarian reform, industrialization, Latin American Integration

\section{INTRODUCTION}

This paper addresses the issue of developmentalism in Latin America from a Latin American structuralist perspective. This means taking as a starting point the studies and premises that ECLAC formulated in the fifties concerning the core-periphery structure of international relations.

From this approach, a counterpoint was raised between the points of view and interests of the hegemonic cores of capitalism: Great Britain first, the United States second (and probably China soon) on the one hand, and the successive peripheral situations that were emerging in Latin America, on the other.

These frames of reference have the present interpretation of the role played by the Alliance for Progress (ALPRO) in the development of Latin America from the late fifties to the early seventies when this great social experiment was demolished by the assassination of the Kennedy brothers and the installation of military dictatorships in South America. In no other Latin American country has this counterpoint between the political processes that characterized the center-periphery relationship been reflected as drastically and clearly as in Chile. On the reciprocal side, it could be said that no other country in Latin America was as far ahead as Chile in its development strategies from the fifties onwards.

Chile's national development strategy, supported by ALPRO, was not only about promoting the development and consolidation of an industrialist State and Class through technical and financial support measures. It required the installation of a greater historical change aimed at creating the economic, social, 
and political conditions so that the powerful rentier classes that controlled Chile's economy could be replaced by a new social class of entrepreneurs, committed to national development, inspired by the instrumental rationality of capitalism and endowed with sufficient technical and economic creativity to promote a process of long-term sustainable development.

Could ALPRO effectively help trigger this major change? On a Latin American scale, on the other hand, the change from the traditional rent culture of economic leadership, to a new business class founded on the authentic instrumental rationality of capitalism and oriented to sustainable accumulation, has been, at all times and until today, an incomplete process, since the generation and adoption of the required technical change was never self-generated in Latin America (and, of course, it has not been in Chile).

The rentier behavior of the economic leadership derives from centuries of foreign trade based on the export of primary products (mining and agricultural) taking benefit of the natural comparative advantages of the different territories and countries of Latin America. This productive and export structure began in the colonial phase. The developmental attitude sought to achieve a profound cultural change in the ruling class required to tackle the industrialist adventure. That change has collided and continues to do so with stubborn resistance from vested interests and pre-existing economic culture.

That is the historical picture that structuralist developmentalism took defining the peripheral condition. To achieve this transformation (perhaps one day achievable), the issue had to be raised on a Latin American scale. From there arose the protectionist, industrialist, and integrationist strategy for Latin America accepted and shared by the ALPRO, which characterized the ECLAC program initially inspired by Prebisch's ideas at the end of World War II.

\section{ECLAC'S DEVELOPMENTAL PROGRAM}

The ECLAC program was certainly not an abstract inspiration unprecedented in the economic history of the Western world, since the strategy had already been successful in the experiences that led to the development of two major powers that emerged on the world economic stage throughout the nineteenth and twentieth centuries: the United States and Germany. The works of Alexander Hamilton, Federico List, and Henry Carey, among others, illustrate the ideas that guided these important historical processes.

For Cepalino-Prebischiano structuralism, the developmental process had to be approached, at least on a South American scale, with a long-term horizon. Hence the need for an integrationist strategy that, at least until today, we have verified, failed to prevail.

The most distinctive and profoundly transformative feature of ALPRO in the case of Chile was to enable the agrarian reform to open the way to that essential transformation aimed at ending the ancestral hegemony of the rentier owners - not only the farmers but also the miners- installed since the Iberian conquest and colonization.

Starting from the perspective of the core-periphery structure of international relations, this wider reform was a precondition for the promotion of industrial development and required the "permission" (consent, tolerance, flexibility) of the main hegemonic core. And the ALPRO led by John F. Kennedy accepted that shared challenge that, from ECLAC, Latin American structuralism proposed to it.

The challenge involved aspiring to the transition from a colonial and/or neocolonial heritage that was very gravitating even in rural areas, to a peripheral capitalism that did not yet fully exist. This transit was the first condition for generating the capitalist structures in the Latin American economies from which the great industrialist strategy could only be considered. The expressions "capitalism", "pre-capitalism" and "semi-capitalism" was used repeatedly by Raúl Prebisch in different sections of the first part of the 1949 Economic Survey of Latin America that he directed, the first of a long series of annual reports prepared by ECLAC that has continued to this day.

Capitalism is a system in which all the factors of production (capital, workers, technological knowledge, natural resources) become commodities (which includes the salaried labor force), acquire a price, and are traded in organized markets. This system also implies the existence of a capitalist, innovative and entrepreneurial business class oriented to profit and the accumulation of capital, as opposed to the figure of the landowner or the rentier mining owner, typical of neocolonial Latin American rural societies. Rural 
haciendas were compartments or micro-worlds where the peasantry was subjected to subsistence selfconsumption regimes highly excluded from national market circuits.

In the late fifties and early sixties of the twentieth century, the rural social structures of all Latin American countries contained the largest percentage of their total populations and still continued to exhibit significant traits of pre-capitalism and semi-capitalism. Even in Argentina, where the late incorporation into the world market generated an extraordinary boost to the growth of that country in the late nineteenth century, there were large areas of its national rural territory where those hybrid features predominated.

Chile was perhaps the only South American country where these revolutionary transformations, agrarian reform, and "Chilenization" of mineral wealth, were attempted by the State with declaredly developmental intention. It was not, of course, a peaceful and coordinated process, and it meant an acute social struggle that involved successive governments of different ideological signs, which, without intending it, since the late forties of the twentieth century, ended up creating a scenario conducive to the installation of a new business class at the beginning of the eighties. Although many of the constitutive surnames of "the new business class" were the same as those of the traditional oligarchy, the new entrepreneurs represented rationality that replaced -not completely, but to a growing and decisive degree the traditional rentier classes that dominated mining and agricultural production in Chile's economy. This new class of entrepreneurs educated in the United States tried to impose, hand in hand with neoliberalism that, parallel and simultaneously, began to rule in the Western centers, a germ of peripheral capitalism ${ }^{1}$. productively somewhat more diversified, but always supported by the exploitation and export of natural resources.

But this germ did not succeed in growing towards a more diversified industrial development, because the historical inertia of peripheral semi-capitalism, and the inherited regional fragmentation in a large number of relatively small economies, together with the pressures and interests of the main hegemonic core, tended to reestablish the modalities of the peripheral style of growth called primary-export by ECLAC and renamed as extractivist in more recent periods ${ }^{2}$.

In short, in the second half of the twentieth century, the old traditional structures inherited from the colonial phase and sustained throughout the nineteenth century were dismantled, but it was not possible to create the objective national and international conditions to attempt an autonomous and sustained industrial development.

At the heart of the developmental ideal formulated by Latin American structuralist thought, the diagnostic point was the historically confirmed verification of the concentration of technical progress and its fruits in the development of the world's economy, with its obvious repercussions on the Latin American process $^{3}$. This concentrating process was verified both in the hegemonic centers concerning the vast world periphery on an international scale and within the Latin American periphery itself concerning the national or local social segments favored by the functioning of peripheral capitalism.

The notion of structural heterogeneity was the synthetic name coined by ECLAC to refer to the longterm economic, social, and cultural effects derived from this concentration within Latin American societies of the time. The notion of structural heterogeneity has a deep historical content that in its origins dates back to the time of conquest and colonization and in its subsequent evolution covers the entire nineteenth century and the first half of the twentieth century. The notions of pre-capitalism and semi-capitalism (typical of the colonial heritage) are essential to characterize the content of the notion of structural heterogeneity. ${ }^{4}$

The greatest transformations in this picture, in the case of Chile, began to take place in the late forties with the succession of radical governments that preceded the government of Jorge Alessandri, contemporaneously with the emergence of ECLAC and preceding the installation of ALPRO.

Strictly speaking, developmentalism refers to the transformative diagnoses and strategies of situations of underdevelopment, for which most of the studies we are mentioning here in footnotes were written in the same decade in which ALPRO was launched. ${ }^{5}$

The Chilean process has played an exceptional role in the adventures of the core-periphery relationship that took place in Latin America during the fifties, sixties, and seventies of the twentieth century. In the fifties, the succession of radical governments that preceded the presidency of Jorge Alessandri Rodríguez implemented a series of industrialist policies that, deliberately or not, meant energetic steps forward in the 
direction of developmentalism that was later to be preached by ECLAC in its collaborative action with ALPRO.

In the sixties, the structural reforms in Chile were presented as an alternative to the Cuban Revolution through the so-called Revolution in Freedom promoted by the government of Eduardo Frei Montalva. Later this exceptional social and political behavior of Chile was manifested in the socialist government of Salvador Allende when the progressive strategy of the democrats led by J.F. Kennedy was defeated within the United States after his assassination (and that of his brother Robert). Then, after the transitional period of Lyndon Johnson, and the subsequent victory of Richard Nixon, the old formula of the "Big Stick" began to be replaced, managed by his Secretary of State Henry Kissinger that culminated in the military dictatorship led by Augusto Pinochet. That regime, installed with the help of the CIA, was an experimental outpost of neoliberalism, very distant and opposed to structuralist ideas, in the Southern Cone.

The new conservative social experiment was intellectually promoted by the doctrines of Von Hayek and Milton Friedman that inspired the economic management of the (so-called) "Chicago Boys" during the second phase of the Chilean military dictatorship.

\section{The Frame of Reference in the International Order}

First of all, it is appropriate to recognize both the global historical-institutional context in which the ALPRO initiative took place, as well as the impact it generated on the Chilean process.

The end of World War II meant turning the page on the historical conflicts between the post-war Western powers and restarting again after a black war period for humanity. Capitalism on an international scale was reconstituted with a single hegemonic center on a global scale: the United States, a country that led the reorganization of the world economy with the creation of a new monetary-financial order articulated around the World Bank and the International Monetary Fund. In addition, a restructuring of the world market took place based on a liberal conception of the world and controlled by the General Agreement on Tariffs and Trade better known by its acronym in English GATT. Some have designated that period as the "golden age of capitalism" or "the thirty glorious years" extolling the expansion, unprecedented until that date, of the post-war world economy.

But there would also be reasons to consider that thirty (1945-1975) as the golden age of democracy in the Western world. Indeed, at the end of the Second World War, events took place as momentous as the political independence of a significant fraction of Asian and African countries oppressed by colonial empires, the founding of the United Nations (UN), and the spread of a new ethic based on the defense of the principles of peace, cooperation and human rights (Charter of the United Nations 1945, Declaration of San Francisco 1948).

From the UN Foundation, a large number of sectoral agencies aimed at the defense of civil, economic, social, and cultural rights such as WHO, FAO, ILO, UNESCO, UNICEF, etc. took place. These institutional transformations were projected into the political sphere leading to the emergence of regimes known as social democracy or social states, based on which European political systems were rebuilt and restructured.

In the more developed countries of the Western world, Keynesianism was imposed as a new conception of political economy that legitimized the functions of the State in monetary, fiscal, and commercial policies. At the same time, in the former colonies that achieved independence in Asia and Africa, the developmentunderdevelopment dichotomy became very strong, with the emergence of a new discipline: the theory of economic growth that, very soon, expanded and deepened into a more comprehensive discipline: the theory of development. UN agencies were instrumental in the installation of these new disciplines.

The influence of the UN on these new interpretations of capitalism and democracy was also felt through the regional economic commissions, one of which was the Economic Commission for Latin America (ECLAC), which elaborated a Latin American structuralist interpretation of development and underdevelopment. The notion of "developmentism" ¿developmentalism?) associated with these processes cannot be dissociated from the broader international framework referred to here.

Secondly, the other historical process that most directly and immediately influenced the launch of ALPRO was the east-west struggle known as the Cold War in which left-wing ideologies -led on a global scale by the Soviet Union - were confronted with the principles and foundations of Western capitalist 
democracies. This process was strongly noticed in rural areas of Latin America, especially since the Cuban Revolution (1959).

In Latin America, the confrontation between U.S.-led liberal capitalism and centrally planned politically authoritarian economies had been manifesting itself not only in the advance of armaments but also in the struggle to increase their respective spheres of influence. At the level of ideas and ideologies, this process led to the incorporation of a set of governments constituting the "third world" in countries of recent decolonization located in Asia and Africa.

In the case of the Latin American countries that had obtained their political independence at the beginning of the nineteenth century, "national and popular movements" (populist for their liberal critics) emerged. Such was, for example, the case in Brazil during the presidency of Getulio Vargas and Juan Perón in Argentina. These governments looked with hostility at liberal ideology (particularly the dogmas of free trade and the self-regulated market) and the dominant influence of the large hegemonic centers and sought to develop their industry to achieve greater productive autonomy.

The Cuban Revolution of 1959 exerted a dramatic impact on the pre-existing ideological climate, opening the option of a guerrilla strategy, which transcended the mere confrontation of ideas and ideologies. Very quickly the Cuban Revolution was co-opted by the Soviet Union induced in part by the United States' frontal opposition to Cuba: a small great enemy that emerged a few kilometers from its shores.

At that historic moment, Democrat John F. Kennedy assumed the government of the United States, a country that suffered from acute internal political problems. Eager to promote the civil rights of the black population subjected to segregation within the southern states of the country, and pressured by peace movements protesting against the consequences of the Vietnam War, the president had to face this new geopolitical threat very close to the U.S. territory.

Faced with this complex scenario, the government led by Kennedy acted simultaneously on two planes. On the one hand, at the military level and through the CIA, an invasion of the island of Cuba was scheduled, which was undertaken by Cuban exiles supported by US war material. This option, typical of traditional U.S. military interventionism when its interests were threatened, had the reluctant consent of J.F. Kennedy but failed very quickly with a resounding defeat of the invaders on the beach of the Bay of Pigs.

At the same time, to neutralize the influence of the Cuban Revolution, Kennedy, eager to legitimize a new style of relationship, began preparing a vast plan to help Latin America launched in 1961 under the name of the Alliance for Progress (ALPRO).

Even today, more than half a century after the emergence of ALPRO, it is difficult to characterize the meaning and impact of this initiative. The ALPRO was not presented as an action purely induced by the fear of proliferation of communism in Latin America in the form of financial aid aimed at curbing the Soviet presence on the continent. On the contrary, President Kennedy presented ALPRO as a transformative bet aimed at the development of the region as long as such development took place within the institutional frameworks and moral values admitted by liberal capitalist democracies in their post-war versions. To this end, in the launch speech of his ambitious initiative, Kennedy rhetorically appealed to seemingly shared historical processes that twinned "The Americas" within a common Pan-American version.

For the first time in the history of "The Americas", a U.S. president clearly opted for a transformative alternative that confronted the conservative forces within not only Latin America but also the United States itself. At that historic moment, Kennedy opened many fronts hostile to his government, internal and external, which, perhaps, contributed to his assassination a couple of years later.

To launch ALPRO, the theme of east-west confrontation was presented by Kennedy as the defense of freedom between nations that, on an equal footing, fought for a common destiny ${ }^{6}$.

But this position of the US president was not pure rhetoric, but, in addition to financial support to the region, it promoted genuine and profound structural transformations such as land reforms, economic integration, planning (or programming) of industrial development, the fight against extreme economic inequality, etc. ${ }^{7}$

Kennedy's speech obviously omitted any reference to the multiple imperial aggressions of U.S. power that had manifested themselves since the Monroe doctrine had sentenced "America for the Americans", and the president uniquely identified the political freedom of Latin American countries with the brotherhood of 
"The Americas" 8 Examining that historic moment from today's perspective, it can be seen that Kennedy offered an effective reforming alternative to social change, backed by institutional and financial aid. And in doing so it was highly inspired by the opinion of Latin American leaders of the moment.

\section{The Alliance for Progress and the "Revolution in Freedom" by Eduardo Frei}

The historical process that led to the launch of the ALPRO had many points of convergence with the expansion of Christian democracies in Latin America, particularly in Chile (Eduardo Frei Montalva) and In Venezuela (Rafael Caldera).

In the case of Chile, Eduardo Frei Montalva assumed the presidency of the country three years after the launch of the ALPRO but has probably been the Latin American political leader who most advocated the regional integration also promoted by the ALPRO, and in that Latin-american task "tuned in" and accompanied the messages already formulated by Raul Prebisch from ECLAC. In addition, Frei Montalva had an industrialist historical background strongly developed during the radical governments. These previous historical processes will be referenced below.

The letter that, at that time ${ }^{9}$, President Frei prepared was addressed jointly to Raúl Prebisch (main inspiration of the reforms), to José Antonio Mayobre (Prebisch's successor in the Executive Secretariat of ECLAC), to Felipe Herrera (president of the IDB) and Carlos Sanz de Santa María (president of the InterAmerican Committee of the ALPRO and participant in the study group on Latin American integration) ${ }^{10}$. In this communication, Frei Montalva indissolubly linked the promotion of industrialization with the process of regional integration that should accompany and complement it. Incidentally, Felipe Herrera (one of the recipients of Frei Montalva's letter) was Chilean and had been appointed (with the obvious consent of the United States) as president of the IDB, considered at that time "the Bank of Integration."

The following textual paragraphs not only include a biographical reference to Felipe Herrera but also describe the political environment of profound changes that were taking place in Chile from the post-war period:

"Felipe Herrera studied at the School of Law at the University of Chile (1940-1947)in a period of complex transformations, with changes of all kinds that meant the growing interest and ascent of the middle class to political power, and a new economic role of the State that spread throughout the continent after the Economic Crisis of 1929, and that was consolidated with the effects of the Second World War, favoring the different projects of industrialization by import substitution (ISI) that the developmental governments of the time sought to implement.

These structural changes directly affected the internal politics of each country, provoking the attention of many young university students who sought various ways of participating in and influencing the happenings of each country. In Chile, the triumph of the Popular Front, which came to power in 1938 with the Presidency of Pedro Aguirre Cerda, was the result of a historical process that had been taking shape along with the exhaustion of the old historical project constituted by the post-Independence elites.

The arrival of Aguirre consolidated the political awakening of several generations of Chileans who had entered into public life with the campaign that brought Arturo Alessandri Palma to power for the first time (1920) and with the Economic Crisis of 1929 that impoverished the middle class, while leaving their political positions. The young people who were educated and raised in these decades drank from these sources and in their time became the protagonists of the recent history of Chile, who carried forward the ideology that then began to take shape: compulsory school education, secular and business state, and public policy with social sense." 11 
The importance of the link between the process of regional integration and the process of industrialization found its previous solid foundations in the diagnosis elaborated in the Economic Study of Latin America of 1949, in which Raúl Prebisch exposed the essential features of the core-periphery structure of international relations and its industrialist message. Another issue that was jointly promoted by both Raul Prebisch and Eduardo Frei was the idea of agrarian reform. As we have seen, these initiatives were put at the heart of John F. Kennedy's proposals when the Alliance for Progress ${ }^{12}$ was launched.

This version assimilated by Kennedy expressed the moment of the maximum degree of influence on the part of Latin American leaders on the policies of the United States towards Latin America and must be understood in the context of the serious challenges that the Cuban Revolution had opened up since 1959. The "alternative model" was precisely the "Revolution in Freedom" formulated by the Christian Democracy led by Eduardo Frei Montalva. ${ }^{13}$

\section{The "Proto-Developmentalism" of the Radicals}

We can find as a starting point in a global perspective of this period an institutional picture in which the "Right" were the Catholic conservative forces supported essentially in the rural and social base dominated by the system of the hacienda that subjugated and marginalized the majority of the Chilean peasantry ("tenants" and "foreigners"), under strongly traditional social relations (pre-capitalist or semicapitalist). To the "center-right" were the liberal forces of mining entrepreneurs, merchants, financiers, and providers of other services linked to the export complex. These political forces were well organized and advocates of private property in close alliance with the conservative landowning oligarchy, but they were anticlerical and promoters of a secular civil society. The "center-left" were the radicals, representatives of the urban middle classes linked to small and medium-sized enterprises, the emerging liberal professions, the enlightened technocracy of the public apparatus, the teachers of public education, and the urban bureaucracy in general. The "left" were the socialist and communist parties representing the urban working class (industrial and mining) and the neglected peasant interests. Their organizations were generally outside the law and subjected to frequent persecution.

The concurrent radical government (Pedro Aguirre Cerda between 1938-1941; Juan Antonio Ríos between 1942-1946 and Gabriel González Videla between 1946-1952), contributed early to propose a developmental ideology that Del Pozo summarizes as follows:

"The first of these, the possibility of choosing the option of industrializing the country was a decisive element for the prospect of changing the face of the Chilean economy; the second, state intervention, carried strong ideological significance because it could mean a substantial change in the orientation of the country's economic regime. The third element, education, and labor played a much less important role, which is not easy to explain at first, and perhaps how infrequent these issues were discussed - especially educationindicates a lack of determination of the authorities to arrive at an in-depth discussion about the transformations that were being announced. A fourth issue could perhaps be considered here: the attempt to seek markets within Latin America, particularly Argentina, with which discussions were held on the subject. However, this aspect will be neglected because it did not become a constant theme through the three radical governments and because it finally became a topic of limited discussion; ten or fifteen years later, in the middle of that time of projects on Latin American integration, this topic would have had another meaning". ${ }^{14}$

From the three mentioned government periods, Gonzalez Videla's, being the last in the sequence, was the one that could present a balance and summary of the "quasi-developmental" achievements of radicalism. In addition, González Videla had made explicit his interest in industrialization even using the name "industrial revolution". But one of the features of radicalism in Chile that differentiated it from socialism was precisely the reformist character of its transformations, and, at that historical moment, (1947) the eastwest struggle that later resulted in the "cold war" was already present; therefore, the international scene 
increasingly tended to a polarization where, in Chile, the alliance with communism was not compatible with the post-war Western order. These aspects gave rise to the history that the left remembers as González Videla's betrayal of the communists who had supported him at the beginning of his term but who were increasingly demonized as the cold war deepened.

The first two radical governments took an ambivalent view of industrial development. Only Gabriel González Videla assumed with more strength and determination an industrialist position, as he expressed when inaugurating the steel industry of Huachipato in 1950:

"Steel, electricity, oil, and mineral smelting are the granite bases on which the economic future of the Chilean nation will rest. The generations of the future will be able to look smoothly at their future days because the national economy will have such a solid foundation that no disaster in the world will be able to break it and affect it as has happened until today when it has remained in a semi-colonial economic stage. This is what I have called an Industrial Revolution in our country." 15

In this regard, del Pozo adds,

"Yes, González was bolder in his speech in favor of the industry, this is explained by two fundamental reasons. The first of these derives from the fact that his presidential term was situated, chronologically (1946-1952) in the years during which the infrastructure works that had been initiated during his predecessors were inaugurated. Such was the case with hydroelectric power plants, Huachipato, and the beginnings of oil production. And the second reason is that during his presidency there was an institutional and ideological context of an international nature in favor of industry, thanks to the foundation of the Economic Commission for Latin America (ECLAC) whose inaugural meeting was held precisely in Santiago, in 1948."

Consequently, always following Pozo, of the three radical presidents, the first two would not come to designate industrialization as a mobilizing objective, but not the third government, although ironically, that speech came into contradiction, with the political turn of the Videla government against the left, which diminished the impact of his speech.

\section{The Government of Carlos Ibañez del Campo}

The three lustra between 1952 and 1964 were transitional years. During the government of Carlos Ibáñez del Campo, who succeeded the trio of radical governments, the price of copper dropped (Chile's main export product) that reduced foreign exchange earnings and the import capacity required for industrial advancement. The government devalued the peso, with the consequent rise in the cost of imports and living. The distributional struggle led to wage adjustments especially in companies and public sector agencies and resulted in government support for industrial enterprises. All this led to greater balance-of-payments imbalances and further devaluations, restarting the inflationary cycle.

The reaction of the ibáñez del Campo government highlighted the correlation of political forces where the center-right still clearly predominated. After successive consultations with the leader of the emerging Catholic Falangist movement (Eduardo Frei Montalva) and a fleeting economy minister of "tenuous" socialist ideas (Felipe Herrera), the government rejected the developmentalist-structuralist suggestions (in line with the recommendations of ECLAC in the sixties) and requested the advice of the US agency Klein Saks that recommended restrictive measures, in the style of those that would later be implemented frequently from the IMF. Inflation, however, continued to gallop, emphasizing that liberal-monetarist diagnoses ignored the structural conditions in Latin America that were being exposed by ECLAC's structuralist studies.

In the government of Ibañez del Campo (1952-1958), the creation of crucial works for the installation of a lasting process of industrial development in Chile was continued. The creation of the National Oil 
Company in 1950 (ENAP), the Pacific Steel Company in 1946 (CAP), was followed by the National Sugar Industry in 1953 (IANSA), all within the framework of the great business creation strategy carried out by the Corporation for the Promotion of Production (CORFO).

Special mention deserves the creation of the Ministry of Mines (1953), and within it, the Department of Copper thinking about the future nationalization of this strategic resource, a fact that, under new historical circumstances, took place during the socialist government of Salvador Allende.

During his presidential term, Ibañez del Campo achieved a great ideological and political affinity with the Argentine government of Juan Domingo Perón. In the same line of the redistributive orientations promoted by Perón in rural areas of Argentina, Ibañez managed to implement the fixing of a peasant minimum wage, which allowed hundreds of thousands of Chilean peasants, who lived under an ancestral remuneration system that had been dragging on since the seventeenth century, out of a state of extreme poverty and subordination.

Considering together the economic orientation of both the radical governments like the Ibañez del Campo, it is possible to highlight two conclusions. First, the enormous influence of ECLAC's ideas on ALPRO. The topic was already discussed in previous sections. Secondly, recalling that ECLAC's structuralist-developmentalist ideas were elaborated since the late forties (1949) and that the headquarters of that organization was located in Santiago de Chile, the influence of the "proto-developmentalist" strategies of the Chilean radical governments on the recommendations of ECLAC, which were assumed and accompanied by ALPRO, could also be hypothesized.

In short, the fundamental feature of these historical processes would be the crucial role to be attributed to Chile in the genesis of the developmentalist ideas that were picked up first by ECLAC and then by ALPRO.

Ibañez del Campo was succeeded by Jorge Alessandri, son of Arturo Alessandri. To both (father and son) were given the "kick-off" to new political cycles. Arturo Alessandri opened the way to the reforms (with some proto-developmentist (iproto-developmentalist?) content) of the radical presidents, and Jorge Alessandri created the conditions for the subsequent governments of the reformist Christian Democrat Eduardo Frei Montalva and the socialist Salvador Allende.

\section{The Government of Jorge Alessandri Rodríguez}

Jorge Alessandri Rodríguez was born in 1896, was the son of Arturo Alessandri Palma known as "the lion of Tarapacá", who was president of Chile twice during the first half of the twentieth century (19201925 and again in 1932-1938) ${ }^{16}$

In 1925, Jorge Alessandri Rodríguez was elected deputy for Santiago with a large majority. His administrative and managerial capacities, together with the considerable influence of the family surname led him to the presidency of the Mortgage Credit Savings Bank 1932, an important predecessor of the Bank of the State of Chile, a position he held until 1938.

At the beginning of the presidency of Pedro Aguirre Cerda, Jorge Alessandri gave another strong proof of the economic gravitation of his family when he was elected president of the Compañía Manufacturera de Papeles y Cartones (CMPC), known as "La Papelera", a powerful Chilean forestry and industrial holding company belonging to the Matte group since $1920 .{ }^{17}$ Since then and until now, the Alessandri family has continued to be an important political arm of the Chilean oligarchy. These references perhaps somewhat detailed serve to illustrate to this day what Alberto Edwards Vives characterized as "the aristocratic froth" (1928). In 1947, Jorge Alessandri was appointed Minister of Finance by radical President Gabriel González Videla.

The decisive elections that led to the presidency of Jorge Alessandri Rodríguez gave rise to a partisan political cadre that would anticipate the political struggle of the following ten years. At the end of June 1957, the XX Ordinary National Convention of the Radical Party proclaimed Luis Bossay Leiva as the sole candidate of that collectivity. This, as a deputy, had represented Valparaíso and was later elected senator for the same province. During the government of Gabriel González Videla held the portfolios of Labor and Economy. 
At the same time, on July 28, 1957, the act of formation of the Christian Democratic Party was signed, which merged the National Falange, the Christian Social Conservative Party, and some independent groups. The new Party lifted the candidacy of Eduardo Frei Montalva.

Almost simultaneously, on September 15, 1957, the National People's Convention took place, which brought together the parties of the left, including in this denomination the Doctrinal Radical Party and the Ibañista National Alliance of Workers, along with a Socialist Party reunified two months earlier and fractions of the Democratic Party. At that Convention, Salvador Allende was proclaimed as a candidate. To understand the vicissitudes that led to Alessandri's election, it is appropriate to take into account the proposals, alarming for the oligarchic sectors, to nationalize copper and carry out the agrarian reform immediately proposed by Allende.

The right parties tried to convince Jorge Alessandri Rodríguez to be a candidate. His name was equivalent to sobriety, austerity, and righteousness. As characterized in the media of the time, it appeared as the exact opposite representation to that of the traditional politician. But it is precisely these personal traits that explained his resistance to accepting the candidacy.

The unexpected death of Raúl Marín Balmaceda induced the Conservative Party to propose Jorge Alessandri as a presidential candidate and the Liberal Party joined the proposal.

The great surprise that changed the electoral picture took place when the four aforementioned candidates were joined by Antonio Zamorano Herrera. A relatively unknown former Catholic priest of the small town of Catapilco, who in 1956 had abandoned priestly life, being elected the following year deputy for Valparaíso, as an independent.

Antonio Zamorano tried, in a way, to represent sectors of the left outside the political parties. In this way, the electorate had to choose between the five candidates who stood for the presidential election of September 1958.

Alessandri's election campaign command, with the advice and participation of expert publicists, carried out modern and incisive propaganda that brought to the public the somewhat paradoxical image of "an apolitical politician" and supposedly independent. The image proved extraordinarily attractive to the common man. His election promises advocated less government control of the economy and a policy of price stabilization. An essential part of his strategy was to open the economy to foreign economic interests by making the conditions for foreign investment more attractive.

But the main strategic "move" of the right party was to convince Antonio Zamorano, Catapilco's former priest, to be a candidate. The votes Zamorano obtained could likely have belonged to Allende.

The election was held on Thursday, September 4, 1958, in a climate of calm and serenity. The final counts yielded the following results: Jorge Alessandri Rodríguez (conservative and liberal right): 31.2\%; Salvador Allende Gossens (left led by the Socialists): 28.5\%; Eduardo Frei Montalva (emerging Christian Democracy): 20.5\%; Luis Bossay Leiva (radical center left) 15.4\%; Antonio Zamorano (the "priest of Catapilco"): $3.3 \%$; white and null votes: $1.1 \%$; Abstention was $16.5 \%$.

Thus, Zamorano, "the priest of Catapilco", with just over 3\% of the vote, managed, if not to twist at least delay the course of later history. The candidacy of the socialist Allende had been halted, the conservatism had survived after the figure of Jorge Alessandri Rodríguez and the Christian Democracy had been strengthened as a future reformist alternative under the standard-bearer Eduardo Frei Montalva. It was this new reformist alternative that would prevail again to Allende's socialist option that hung like a sword of Damocles over Chile's political future.

During the government of Jorge Alessandri Rodríguez, two relatively unexpected events occurred. First, a terrible earthquake that struck southern Chile (1960), and second, after the triumph of the Democrats in the presidential elections of the United States, the formation of ALPRO, as a reformist response, to the exacerbated polarization of international positions in the framework of the cold war.

After the earthquake, the government of Alessandri Rodríguez requested economic aid from the United States, but Kennedy responded that that aid would be channeled through the ALPRO that had already been launched. This conditionality to be able to access the required aid is what explains why a conservative government ended up adhering to a bold reformist project such as the one proposed by Kennedy through ALPRO. 


\section{The Agrarian Question in Chile ${ }^{18}$}

The early harmony between the recommendations that ALPRO would make and the course of the reforms that were very timidly beginning to be implemented in Chile can be exemplified very well by the historical course that the agrarian question was taking as reformist pressures intensified in chile's rural areas. It is appropriate here to deepen this aspect of the subject especially considered, both by the ALPRO and by the development strategies that would be undertaken by the governments of the time.

In the 1930s, only $25 \%$ of agricultural land was productive, the rest provided fodder for livestock or was "fallow," agricultural production per capita was declining slightly, and the trade deficit was rising rapidly.

A 1939 study revealed that less than $1 \%$ of all agricultural properties covered $68 \%$ of the land. $47 \%$ of the remaining agricultural plots had an area of fewer than five hectares. The great mass of the rural labor force (about one and a half million "tenants" and "foreigners") survived at the level of subsistence.

President Aguirre Cerda (1938-1941), did not dare to attempt an agrarian reform that would have meant a confrontation with the right-wing of the Radical Party in addition to the repudiation of conservatives and liberals with rural interests. The National Society of Agriculture that nucleated these interests fought against agricultural unionization and managed to hinder and even annul these processes, and this situation was not modified either during the presidency of Ríos (1942-1946).

When President González Videla, also a member of the Radical Party, took the government, he expressed an ambivalent attitude, the result of which was ultimately the issuance of a very limited and restrictive rural union law.

Even so, hundreds of unions were more or less immediately created, which began to press for improvements in their employment contracts. González Videla's break with the communists who had helped him win the presidency led to a new law that banned agricultural strikes and severely restricted the specter of unionization in the countryside.

Finally, during the government of Jorge Alessandri Rodríguez (1958-1964), the first agrarian reform that existed in Chile was approved. The law enacted in 1962 made it possible to expropriate land with payments of $20 \%$ in cash and the rest in long-term bonds. Although the law was put into practice only to a quantitatively negligible extent, it established the institutions (rules of the game) and organizations (public sector agencies) that would enable the beginning of the reform process during the government of Eduardo Frei Montalva. The organizations created by the aforementioned law were the Corporation of Agrarian Reform (CORA) to oversee the process of legal expropriation; the Consejo Superior de Fomento Agropecuario (CONFSA), Higher Council for Agricultural Development, aimed at seeking the most effective forms of productive use of expropriated land, and the Instituto de Desarrollo Agropecuario (INDAP), Agricultural Development Institute, dedicated to providing technical and credit assistance to the beneficiaries of agricultural redistribution. It should be reiterated that Jorge Alessandri "opened the door" of the Reformation, but "did not cross the threshold." That was the task that fell to Eduardo Frei Montalva

The conservative-liberal right-wing government led by Jorge Alessandri, paradoxically given its ideological position, ended up being the promoter of the first agrarian reform in Chile. This attitude is explained, it should be reiterated because the earthquake of 1960 left thousands of dead, and when the Chilean government requested help from the United States, it channeled its assistance through the ALPRO regulations, which forced the incorporation and support of Alessandri to this hemispheric initiative that, we know, included as one of its main pillars, precisely the Agrarian Reform.

\section{"Revolution in Freedom" by Eduardo Frei Montalva (1964-1970) Frame of Reference}

Eduardo Frei Montalva held the presidency of Chile during the period 1964-1970. His government marked a real historic break in the Chilean political landscape. His political movement "the phalanx", was a detachment from the old Catholic conservative party and expressed a dramatic turning point in the political and social positioning of the Catholic Church. This important mutation was because of a consequence of the strengthening of a new social doctrine of the Church, especially from the pontificate of John XXIII and the Second Vatican Council, which was convened by him, and brought to its culmination by his successor 
Pope Paul VI. The presence of the new Christian social thought was already very explicit in philosophers such as the Frenchman Jacques Maritain (a personal friend of Frei Montalva). They were the ideologues of the currents Christian Democrats who would be born in Europe, also having a special impact on Chile. It is interesting to note that Maritain was an important anonymous ghostwriter of the Universal Declaration of Human Rights adopted and promulgated by the UN in the late forties.

Like their European counterparts, the Chilean Christian Democratic Party, they did not have a restrictively Catholic confessional character nor did they initially have the unconditional support of the Chilean Church. The first Chilean cardinal, Monsignor José María Caro, accused them of being too soft on the communists. On the other hand, the conservative political forces granted a certain tolerance to the Christian Democrats, thinking that their reformist proposals were electoral rhetoric that would decline when they took over government positions. However, the Christian democracy's electoral slogan transparently reflected its real intentions to make a "revolution in freedom". This denomination examined in the perspective of the east-west confrontation of the Cold War on a global scale, and the spread of Marxist ideology in Latin America, was a response or retort to the Cuban Revolution that since the late fifties defied the Pan-American order led by the United States, and helped to trigger the ALPRO.

The "Revolution in Freedom" that would be strongly supported by the United States through the ALPRO was thus shown as an alternative course of action not only for Chile but also for the future of Latin America. In the case of Chile, this was to translate into an effort to incorporate rural and urban marginal forces into political and social participation, through two major initiatives: popular promotion and agrarian reform.

In addition to these measures, the developmental orientation of the Frei Montalva government was expressed through the "Chilenization of Copper", the stimulation of the industrialization process, the elaboration of development plans required for the search for international financing, and of course the Latin Americanist vocation of regional integration.

\section{Social Marginality and Popular Promotion}

The initiatives of the Chilean Christian Democracy referred to popular promotion were inspired by diagnoses that characterized in different ways the, so-called social marginality, a subject originally theorized and deepened with the help of Catholic research centers. Such was the case of the Centro para el Desarrollo Social de América Latina (DESAL), Center for the Social Development of Latin America, led by Roger Vekemans, a Belgian Jesuit priest who exerted a strong influence over the Christian Democratic government of Frei Montalva.

The term "social marginality" differed from Marxist approaches so in vogue at that historical time that linked it to the class structure of capitalism and from the diagnoses of poverty inherited from European experiences (e.g. the notion of industrial reserve army). Nor was it raised solely as a quantitative problem of poverty expressed in insufficient purchasing power of wages.

In this regard, Alexis Cortés observes: "From Vekemans' point of view, marginality differed from poverty in its radicality, since it was a fundamental distinction between a participating sector and a marginalized sector, where the image of a center/periphery is present, not only in the field of international relations but within societies themselves. That is why, under this logic, neither the category of "underdevelopment", nor that of "dependence" realized the specificity of Latin America. For this author (he refers to Vekemans), the problem was that there was not enough cohesion for societies to form a whole. Latin America would be a social unit that as a whole would be in 'becoming', but with an unresolved rupture. To understand this it would be indispensable to cross a vertical dimension of stratification analysis with the horizontality of an internalized 'inside' and 'outside' in society." 19

Other authors such as the Peruvian Anibal Quijano, from a different perspective, but also tracing in the Latin American specificity associated the term "social marginality" with the colonial heritage and the profound ethnocultural discriminations suffered by the native peoples, which were created from the very moment of conquest and colonization.

The so-called Popular Promotion preached by Vekemans was a social reform promoted by the Christian Democracy aimed at organizing civil society. It was a question of creating the institutions ("rules of the 
game") that would allow the emergence of social organizations ("players") such as neighborhood centers, fathers' boards, and mother centers, as well as different local self-help organizations. The ALPRO facilitated, or at least did not oppose, this strategy; it is worth remembering that John F. Kennedy was the only Catholic who had so far succeeded in gaining the presidency of the United States. The spirit of the ALPRO included an overcoming of the structures of "traditional society" in the sense that, for example, the Argentine sociologist Gino Germani would have given to this expression.

From another angle, for the Marxist left the "Revolution in Freedom" could be understood as a step towards the installation of a kind of "democratic-bourgeois reform". That is why some right-wing Catholic authors accused Frei Montalva of having been "the Chilean Kerensky". However, Latin America's "traditional society" possessed non-transferable traits that could not be interpreted with category from the economic and social history of European experiences.

Roger Vekemans' theses on social marginality were important, because they characterized it in its Latin American specificity, differentiating it as a phenomenon from the theses of dependence most associated with the logic of capitalism both from a Marxist perspective (Dos Santos) and "Cepalina" (Cardoso and Faletto). It could be said that the methodology of the Belgian Jesuit involved a historical-cultural analysis inextricably linked to a Catholic view of the Latin American social process.

\section{Agrarian Reform of Christian Democracy}

The international political situation favored and legitimized the process of agrarian reform initiated by the Christian Democracy. Summarizing what has already been said above, on the one hand, the Cuban revolution had highlighted the effective force of the most extreme options that, in Latin America, could conclude simultaneously not only with capitalism but also with democracy (human rights, guarantees, and public freedoms) and, in this way, strengthened the Christian Democratic "reformist" option of the so-called "Revolution in Freedom". Not only ALPRO gave an important role to the Agrarian Reforms as an instrument of development and democratization for Latin America. In addition, ECLAC, located in Santiago, Chile, endowed, at that historic moment, with important convening power, providing great support and technical assistance to the reform options.

Initially, Eduardo Frei Montalva made use of the rules approved during the Alessandri government. He then created his own land reform law. By the end of his term, the Christian Democratic government had expropriated about $25 \%$ of all land considered unproductive and was transforming the rural social structure itself in depth. This result was the most impactful blow ever received by the Chilean landowning oligarchy and was accompanied by a growing recognition of the peasant rights of both the "tenants" and the "foreigners".

At the beginning of his government, the Christian Democracy took advantage of the Agrarian Reform Law of Alessandri, expanding both the CORA and the INDAP and expropriating hundreds of farms until 1967. After a prolonged parliamentary battle facing the general opposition of the right, and the landowners, in particular, the Christian Democracy achieved the required constitutional reform. Thus, Agrarian Reform Law No. 16,625 was signed in mid-1967. Then all the haciendas of more than 80 "basic" hectares were susceptible to be expropriated; the owners were entitled to retain a "reserve" of 80 hectares and compensation in the form of a small cash payment and long-term government bonds. Inefficiently managed estates were the first targets of expropriation.

The most radicalized positions (for example, Jacques Chonchol, vice president of INDAP) wanted to further deepen the process by reaching a total reorganization of the expropriated estates. But the favored peasants themselves preferred to move more slowly, consolidating what had already been done. Initially, the expropriated estates were not subdivided but became settlements worked by an elected committee of peasants and the CORA. After five years, the partners in each settlement had to decide whether they wanted to continue working collectively or subdivide. By the end of Frei's presidential term, more than 900 settlements had been formed: among them, some 100 had already made a decision, most chose to continue as undivided units.

The large landowners, for their part, resisted by all their available means, they supported themselves by trade unions in the Sociedad Nacional de Agricultura (SNA), National Society of Agriculture, promoted 
employers' unions, and associated with small landowners. Some outraged landowners sometimes blocked roads to make their demands public. As the cited authors point out: "Agricultural production increased slightly during the years of the PDC party (Christian Democratic Party), even though 1968 saw the most disastrous drought in the memory of Chileans. Most of this increase came from the 'unformed sector' rather than from the settlements, where much of what was cultivated or raised was understandably consumed by the same partners" 20 .

After these turbulences, the Chilean political picture had changed significantly. On the right was now the "national" party that included the conservative landowners hard hit by the reforms (especially the Catholics) and the far-right liberals who, despite their internal differences, never settled on the religious plane, gathered around the defense of private property and the market economy. At the center of the political spectrum remained the radical party supported mainly by the urban middle classes (small landowners, the techno-bureaucracy linked to the public sector, predominantly secular). In the center-left emerged solidly the Christian Democracy that had managed to put some "bells to the cat" of the rural oligarchy and socially integrate a fraction of the marginalized masses. On the left and taking advantage of the full freedoms in force in the period, the socialist and communist (Marxist-Leninist) parties were strengthened.

Just as Christian Democracy was a left-wing offshoot of Catholic conservatives, so the Chilean socialist party was strengthened by the left-wing radical party. Both shared a secular, Freemason, and anticlerical position, and an appreciation for the leading role of the state in promoting development. However, radicals had greater respect for private ownership of resources and market mechanisms.

The socialists were more influenced by the ideas of both the social-democratic left and Marxism in different and contradictory ways. This "paternity" of the radicals over the socialists is anecdotally highlighted through the biography of the main protagonist of the political drama that was coming: the socialist Salvador Allende who was descended from a family of strong radical convictions.

Agrarian Reform in Chile was a dramatic episode that began with Alessandri, continued with Frei Montalva (stimulated by support from ALPRO), and culminated with the presidency of Salvador Allende. Then came the effort to reverse the process by the military dictatorship of Augusto Pinochet.

As Octavio Avendaño points out: "In short, the peasants passed from one institutional context to another without overcoming, especially in sociocultural terms, those aspects of traditional order. In 'Weberians' terms, an important part of the peasants moved directly from a type of "traditional domination", typical of the tax system, to another of a "bureaucratic" or "rational-legal" type, which defined the agrarian reform legislation and was deployed by the officials of the INDAP and the CORA" ${ }^{21}$.

\section{The "Chilenization" of Copper}

The other economic transformation equally tolerated by Washington was the process called "copper Chilenization." Links can be established with John Kennedy's proposals within the framework of ALPRO here too, which proposed strengthening the negotiating capacities of the Latin American periphery concerning its exports from the primary sector and the international prices of its basic products. As in other reforms under the idiosyncrasies and style typical of Chilean Christian Democracy, the "Chilenization" of copper (acquisition of $51 \%$ of the shares of mining companies) was as a middle ground between two extremes, neither a position favorable to the interests of foreign mining companies nor a complete nationalization as proposed by the programs of communism and socialism.

Thus greater control over American companies was achieved, an increase in production and simultaneously, an increase in the profits of mining companies. These in exchange for tax concessions increased both investment and production. The Frei government called these procedures an "agreed nationalization."

The Copper Department dating back to 1954 was transformed into the Corporación del Cobre (CODELCO), Copper Corporation, from which Chilean officials were much more present in the management levels. Likewise, the industrialization of copper advanced with the construction of new refineries. 
Concerning the terms of trade in the international marketing of copper, the quotations of the London Metal Exchange were applied, which at that time were double those in force until that moment. This meant a large increase in tax revenues for that concept ${ }^{22}$.

\section{Developmentalism in the Industrial Field}

The social struggles unleashed by the agrarian question generated a growing distrust on the Chilean industrial business elites, and the Sociedad de Fomento Fabril (SOFOFA), Federation of Chilean Industry did not support the developmental version of industrialization promoted by the DC, as demonstrated by the decrease of more than $20 \%$ in the coefficient of industrial investments during the period. Thus, a rejection of state interventionism that had been accentuated since the time of Ibañez del Campo continued and deepened. Following the logic of the "self-fulfilling prophecy" in the face of private-sector investment reluctance for fear of an intensification of nationalization, paradoxically the state was forced to play a more active role. Between 1969 and 1970 the State was responsible for more than half of all industrial investment. The Chilean state also did not neglect infrastructure improvements. The hydroelectric capacity was expanded by Empresa Nacional de Electricidad SA ENDESA's, National Electric Company, huge project in Rapel (near Rancagua), which began producing energy in 1968. The Empresa Nacional de Telecomunicaciones (ENTEL), National Telecommunications Company, a new state entity, began operating on a national telecommunications system. The Empresa Nacional de Petroleo (ENAP), National Petroleum Company, set up a refinery in Concepción and continued to prospect for oil in the extreme south. Transport also benefited from the construction of the new International Airport of Pudahuel, the beginning of the metro works (underground train), designed by the French for Santiago, and the excavation of the Lo Prado tunnel of 2.75 kilometers, which considerably shortened the trip of Santiago to Valparaiso.

The State was also active in a series of collective enterprises with foreign firms, especially the petrochemical complex installed in Concepción by the transnational Dow Chemical. Liberal legislation inherited from the Alessandri government on foreign investment was used for the creation of local subsidiaries or the acquisition of domestic firms (such as INSA, the tire company). They began to operate new and dynamic industrial activities such as electronics, pharmaceuticals, car assembly, etc.

"In 1970, some forty of the hundred most successful Chilean companies were controlled by foreign interests, including the thirty major U.S. multinationals. In 1970 foreign firms controlled about $25 \%$ of all industrial capital. Since many of the new industries were capitaldense, they had little impact on employment patterns. Although in the late 1960s Chile produced virtually all types of consumer goods (including non-perishable items such as television equipment and washing machines), much of the capital goods (machinery and equipment) had to be imported. The advantageous terms in which foreign firms operated, their growing importance in manufacturing, the repatriation of their profits, all these aspects were much discussed at the time" 23 .

\section{Development Planning and Regional Integration}

Other elements clearly present in the economic policy of the Frei Montalva government were the foundation of the Oficina de Planificación (ODEPLAN), Office of National Planning, which coincided approximately in time with the preaching of ECLAC on the programming of industrial development (associated with the so-called process of "difficult substitution" of imports) and the foundation of the ILPES (Latin American Institute of Economic and Social Planning) as part of the UN. The influence of ECLACs ideas in the field of regional integration was also present. As noted at the beginning, Chile was a pioneer in signing the Cartagena Agreement that gave life to the Andean Pact: an ambitious regional integration agreement that (within the broader framework of the Latin American Free Trade Association LAFTA) associated this country with Venezuela, Colombia, Ecuador, Peru, and Bolivia. 


\section{CONCLUSIONS}

The ALPRO was a project of a Democratic government that, in the United States, made a great effort to open an alternative reformist path, on a hemispheric scale, in the face of the advance of the radical left parties ideas promoted by the Cuban Revolution. This project went against the current of the traditional imperial ideologies that fed, and have continued to feed, the expansionism and "exceptionalism" of the United States, in the line of the Monroe Doctrine summarized in the phrase "America for the Americans", which in the line of the American imperialist right party was read as "Latin America for the Americans".

The ultimate goal pursued by ALPRO was abruptly eliminated after the assassination of the Kennedy brothers and Martin Luther King. The structuralist worldview, from which the development strategy promoted by ECLAC emerged, was not "hemispheric" nor did it promote an alliance of "The Americas" as intended by John F. Kennedy, but was Latin American, related to the ideals of Simon Bolivar and oriented in the direction of the search for the political unity of the countries located south of the Rio Grande.

\section{ACKNOWLEDGEMENT}

Translated \& edited by American Publishing Services (https://americanpublishingservices.com/).

\section{ENDNOTES}

1. Prebisch, Raul, 1981. Capitalismo Periférico: crisis y transformación. Fondo de Cultura Económica, Mexico.

2. Ahumada, José Miguel, 2018. The political economy of peripheral growth: Chile in the Global Economy. Palgrave Mac. Millan.

3. Pinto, Aníbal, 1965. "Concentración del Progreso Técnico y de sus frutos en el desarrollo latinoamericano", in El Trimestre Económico, volume 32, number 125.

4. Related works: i) Estudio Económico de la América Latina 1949, CEPAL-ONU (e/cn 12/164/Rev.1), New York, 1951; ii) Prebisch, Raul, 1952. Problemas teóricos y prácticos del crecimiento económico, ECLACUN, e/cn.12/221. iii) Pinto, Aníbal, 1968. Naturaleza e implicaciones de la heterogeneidad estructural de la América Latina. In Inflation, structural roots, Essays of Aníbal Pinto, Readings no. 3, Fondo de Cultura Económica, Mexico, 1973. iv) Economic Survey of Latin America, 1968, ECLAC-UN.

5. Related works: i) Furtado, Celso, 1972. La economía latinoamericana desde la conquista ibérica hasta la Revolución cubana, Editorial Universitaria, Chile ii) Sunkel, Osvaldo; Paz, Pedro, 1970. El subdesarrollo latinoamericano y la teoría del desarrollo, Part Four, ILPES Editorial Siglo XX I, México iii) Pinto, Aníbal, 1972, Notas sobre desarrollo, subdesarrollo y dependencia, El Trimestre Económico, Vol. 39, No. 154, pp. 243-264

6. In the ALPRO launch speech, Kennedy noted: "One hundred and thirty-nine years ago, this week, the United States -- moved by the heroic struggles of its brethren in the Americas -- called for the recognition of the newly independent republics of Latin America. It was then, at the dawn of freedom across the continent, that Bolivar expressed his desire to see the Americas become the largest region in the world, "great not so much by its extent and wealth, but by its freedom and its glory."

"Never -- in the long history of our hemisphere -- has this dream been so close to becoming a reality, and it has never been in greater danger."

7. Kennedy's words were about humility and brotherhood not common in the proud speech of the great neighbor to the north: "We invite our friends in Latin America to contribute to the enrichment of life and culture in the United States. We need teachers of your literature and history and tradition, opportunities for our young people to study in your universities, access to your music, your art, and the thought of your great philosophers. For we know we have much to learn. In this way, you can help bring a fuller spiritual and intellectual life to the people of the United States -- and contribute to understanding and mutual respect among the nations of the hemisphere."

"With steps such as these, we propose to complete the revolution of the Americas, to build a hemisphere where all men can hope for a suitable standard of living, and all can live out their lives in dignity and in freedom." 
8. “To achieve this goal," Kennedy continued, "political freedom must accompany material progress. Our Alliance for Progress is an alliance of free governments, and it must work to eliminate tyranny from a hemisphere in which it has no rightful place.

Therefore, let us express our special friendship to the people of Cuba and the Dominican Republic -- and the hope they will soon rejoin, the society of free men, uniting with us in common effort."

"This political freedom must be accompanied by social change. For unless necessary social reforms, including land and tax reform, are freely made -- unless we broaden the opportunity for all of our people -unless the great mass of Americans share in increasing prosperity -- then our alliance, our revolution, our dream, and our freedom will fail."

9. Frei Montalva said in the aforementioned letter: "It is a concept that is no longer discussed in Latin America that all large, medium, and small countries have to share equitably the advantages of industrialization. It would not be permissible among us that the old scheme of exchanging manufactured goods for primary products to repeat old mistakes and injustices. Industrial exchange and primary exchange need to be unwrapped in the vast process of Latin American integration."

10. Mayobre, José Antonio; Herrera, Felipe; Sanz de Santamaría, Carlos; Prebisch, Raul. 1965. Towards the accelerated integration of Latin America: propositions to Latin American presidents. México, DF, Fondo de Cultura Económica México, 1963. Hacia la Integración Acelerada de América Latina

11. Ross, César, 2013. Felipe Herrera: Notas para la historia de su pensamiento Económico 1945-1960”. Instituto de Estudios Avanzados, Santiago, Universidad de Santiago de Chile. Santiago, Chile.

12. It is worth emphasizing the enormous influence of the ideas promoted by ECLAC for the fundamental contents of ALPRO. In this regard, Dosman ${ }^{12}$ (page 357 and following) says that five days before the launch of the Alliance, Raúl Prebisch prepared a draft letter, which was handwritten by him representing ideas held jointly by the highest representatives of ECLAC, the IDB, and the OAS in a new approach to relations between the United States and Latin America. The memo circulated among his colleagues at the other institutions for comment and that same original was sent to Kennedy with the remarks and corrections aside. Some of those ideas were literally incorporated by the US president in his launch speech of the Alliance five days later. That draft memo examined 8 of the 10 core issues included by Kennedy in the PA proposals. Another way to present that same idea would be to say that Kennedy had included substantial parts of the memorandum that had been sent to him from Latin American agencies.

13. This approach is not reflected, may I suggest, in the counterpoint cosmopolitanism-nationalism-populism that is tested in the article on hermeneutics. I only made a superficial reading of it, but I think there would be another approach that could be called Latin Americanism. For this very reason, I think that a crucial aspect of this alternative approach capable of containing the ideas of ALPRO should be the issue of Latin American regional integration tirelessly promoted by Eduardo Frei Montalva, together with the enormous general harmony of the ideas of ALPRO with the diagnosis of Prebisch and ECLAC. (Propongo suprimir esta nota al pie número 13, redactada en polémica contra otro artículo de la Revista Académica en que se publicó este artículo, pero que no se entiende aquí.)

14. Del Pozo, José, 1989. Los gobiernos radicales en Chile frente al desarrollo (1938-1952). Université du Québec à Montréal. Département d'Histoire.

15. Ibid. Speech by González Videla, 1950. Inauguration of the Huachipato steel mill, El Mercurio. "A time of vital transformation of our economic scaffolding with the steel industry begins."

16. The Alessandri family of good economic and cultural position had migrated to Chile in the mid-nineteenth century, to occupy diplomatic positions of distinction and a good position in business. Arturo Alessandri Palma during his presidency represented a typical political conservative populism. He always referred to his abundant and enthusiastic followers as "my dear rabble." That populist-paternalistic expression, which was habitual in him, paints him in the full body for all the implications not only political but also cultural of the period that it implies. But, in any case, it is also true that he exercised an enormous charisma over his abundant followers.

17. "La Papelera" controls Chile's second-largest forest heritage, which is the main input for the industrialization of pulp. This activity extends today to other plants located in Brazil (Rio Grande Do Sul). In 2015 its market capitalization was around 2000 million dollars. The group is led by Bernardo Matte, Eliodoro Matte Larraín, Patricia Matte, Jorge Matte, Eliodoro Matte Capdevila and Bernardo Larraín. According to Forbes Magazine, the Matte group is the third-largest in economic importance in Chile, behind the Luksic Group and Horst Paulmann's Cencosud holding company.

18. In the varied historical references of the rest of this essay there has been abundant consultation with the work of Collier, Simon and Satter, William.1999. , Historia de Chile, 1808-1994, Madrid, Cambridge University Press, Madrid 
19. Cortés, Alexis, 2012. "Modernization, dependence, and marginality: conceptual itinerary of Latin American sociology" Magazine "Sociologias," Porto Alegre, p. 214-238.

20. Collier and Satter, ob.cit., pp. 270-272. For an in-depth analysis of agrarian reform and the Chilean peasant movement see: Avendaño, Octavio, 2017. Los partidos frente a la cuestión agraria en Chile, 1946-1973: representación de intereses, gradualismo y transformación estructural, Santiago, LOM editores.

21. Ibid. From a fundamentally political perspective, see de Avendaño, Octavio, 2017, Los Partidos frente a la cuestión agraria en Chile, 1946-1973, LOM Editores, Santiago de Chile.

22. Collier and Sater.1999., pp.272-273

23. Ibid., pp. 272-274.

\section{REFERENCES}

Ahumada, J.M. (2018). The political economy of peripheral growth: Chile in the Global Economy. Londres, Palgrave MacMillan.

Avendaño, O. (2017). Los partidos frente a la cuestión agraria en Chile, 1946-1973. Santiago, Editorial LOM.

Cavieres, E. (1999). Comercio Chileno y Comerciantes Ingleses, 1820-1880. Santiago, Editorial Universitaria, colección imagen de Chile.

CEPAL-ONU. (1951). Estudio Económico de la América Latina 1949 (e/cn 12/164/Rev.1). Nueva York.

CEPAL-ONU. (1968). Estudio Económico de la América Latina. Nueva York.

Collier, S., \& Sater, W. (1999). Historia de Chile (1808-1994). Madrid, Cambridge University Press.

Cortés, A. (2012). Modernización, dependencia y marginalidad: Itinerario conceptual de la sociología latino- americana. In Revista Sociologias (pp. 214-238). Porto Alegre.

Di Filippo, A. (1981). Desarrollo y Desigualdad Social en la América Latina. Colección Lecturas número 44, México, Fondo de Cultura Económica.

Di Filippo, A. (2013). Poder, Capitalismo y Democracia. Santiago, Editorial RIL.

Drake, P., \& Jaksic, I. (comp.). (2000). El Modelo Chileno, Democracia y Desarrollo en los Noventa. Santiago, LOM.

Fuentes, L. (1997). Grandes Grupos Económicos en Chile. Santiago, Ediciones Dolmen.

Furtado, C. (1972). La economía latinoamericana desde la conquista ibérica hasta la Revolución cubana. Santiago, Editorial Universitaria.

Góngora, M. (1986). Ensayo histórico sobre la noción de Estado en chile en los siglos XIX y XX. Santiago, Editorial Universitaria.

Gurrieri, A. (1982). La obra de Prebisch en la CEPAL. Tomos I y II, Colección Lecturas número 46, México, FCE.

ILPES. (1970). Dos polémicas sobre el desarrollo de la América Latina. Santiago, Editorial Universitaria.

Jara, Á. (1987). Trabajo y Salario Indígena, Siglo XVI. Santiago, Editorial Universitaria, Colección Imagen de Chile.

Kennedy, J.F. (1961, March 13). Discurso del presidente Kennedy sobre América Latina. Documentos Básicos para Alianza para el Progreso.

Mizala, A., \& Romaguera, P. (2005). La legislación laboral y el mercado de trabajo: 1975-2000, incluido. In Reformas, Crecimiento y Políticas Sociales en Chile desde 1973. Santiago, Lom/CEPAL.

Pinto, A. (1965). Concentración del Progreso Técnico y de sus frutos en el desarrollo latinoamericano. In El Trimestre Económico (n. 125). México, Fondo de Cultura Económica.

Pinto, A. (1971). Tres Ensayos sobre Chile y la América Latina. Ediciones Solar, Buenos Aires.

Pinto, A. (1972). Notas sobre desarrollo, subdesarrollo y dependencia. In El Trimestre Económico, (no. 154, pp. 243-264). México, Fondo de Cultura Económica.

Pinto, A. (1973). Inflación, raíces estructurales, Ensayos de Aníbal Pinto (Lecturas núm. 3). Mexico, Fondo de Cultura Económica. 
Pinto, A. (1973). Naturaleza e implicaciones de la heterogeneidad estructural de la América Latina. In $E l$ Trimestre Económico (no. 145). México, Fondo de Cultura Económica.

Prebisch, R. (1949). Problemas teóricos y prácticos del crecimiento económico (CEPAL-ONU, e/cn.12/221). Chile, Santiago. También disponible en Prebisch, Raul. 1969. Ensayos de interpretación económica. Santiago, Editorial Universitaria.

Prebisch, R. (1981). Capitalismo Periférico. Crisis y Transformación. México, Fondo de Cultura Económica.

Sunkel, O., \& Paz, P. (1970). El subdesarrollo latinoamericano y la teoría del desarrollo, Parte Cuarta, texto del ILPES, México, Editorial Siglo XXI.

Titelman, D. (2001). Las Reformas al Sistema de Salud: Desafíos pendientes. In R. Ffrench Davis \& B. Stallings (Eds.), Reformas, crecimiento y políticas sociales en Chile desde 1973 (pp. 263294). Santiago, LOM/CEPAL.

Villalobos, S. (1992). Chile y su historia. Santiago, Editorial Universitaria, Colección Imagen de Chile. Villalobos, S., Silva, O., Silva, F., \& Estellé, P. (2000). Historia de Chile. Santiago de Chile, Editorial Universitaria. 